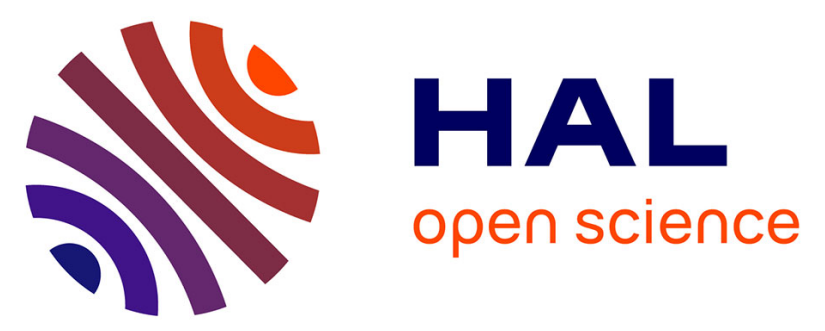

\title{
Improvement of partition coefficients determination of aroma compounds in food matrices by the phase ratio variation method
}

Anne Tromelin, Samuel Lubbers, Isabelle Andriot, Elisabeth Guichard

\section{- To cite this version:}

Anne Tromelin, Samuel Lubbers, Isabelle Andriot, Elisabeth Guichard. Improvement of partition coefficients determination of aroma compounds in food matrices by the phase ratio variation method. Flavour Science: Proceedings from XIII Weurman Flavour Research Symposium, Academic Press, 742 p., 2014, 978-0-12-398549-1. 10.1016/B978-0-12-398549-1.00075-1 . hal-01298407

\section{HAL Id: hal-01298407 \\ https://hal.science/hal-01298407}

Submitted on 5 Jun 2020

HAL is a multi-disciplinary open access archive for the deposit and dissemination of scientific research documents, whether they are published or not. The documents may come from teaching and research institutions in France or abroad, or from public or private research centers.
L'archive ouverte pluridisciplinaire HAL, est destinée au dépôt et à la diffusion de documents scientifiques de niveau recherche, publiés ou non, émanant des établissements d'enseignement et de recherche français ou étrangers, des laboratoires publics ou privés. 


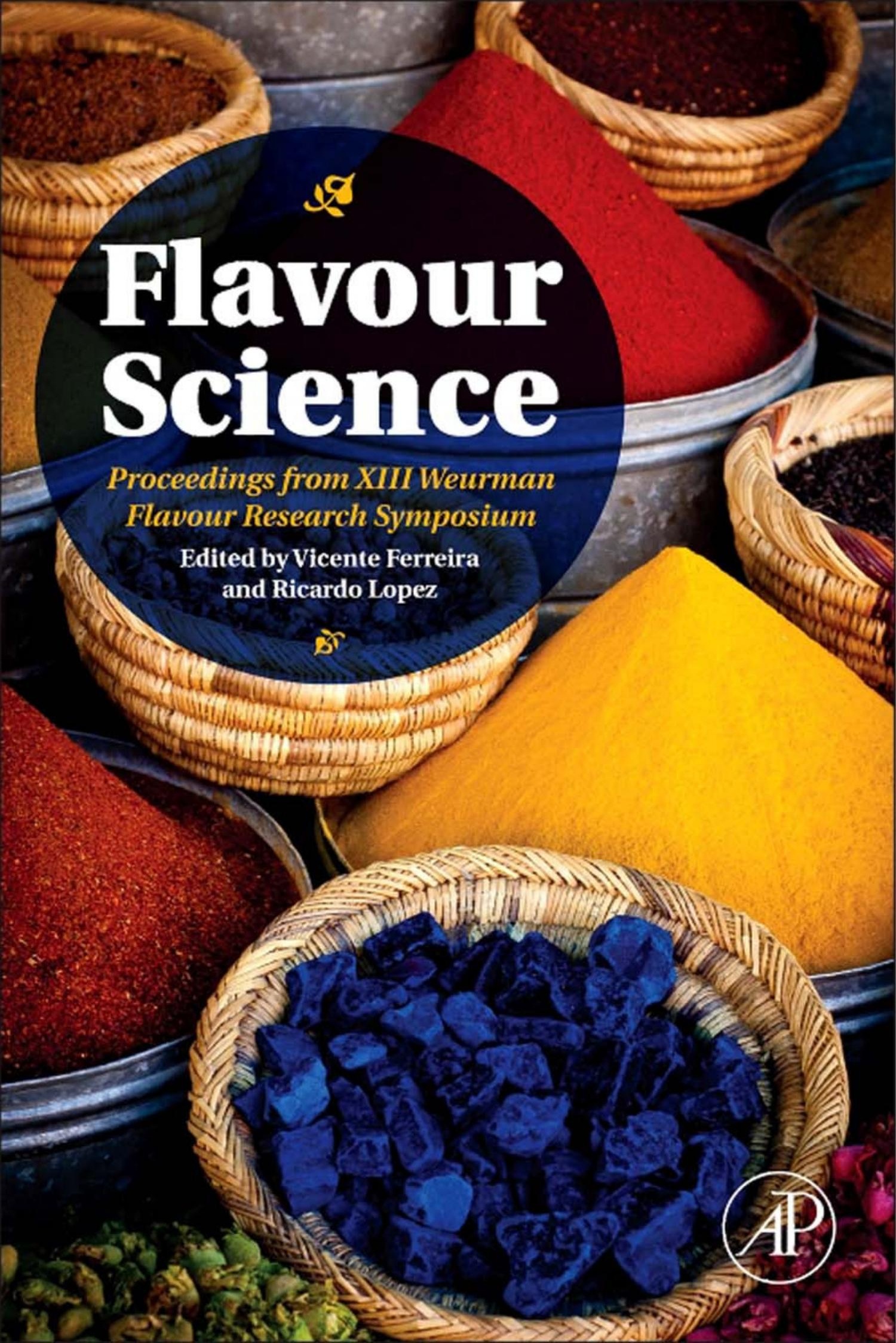




\section{FLAVOUR SCIENCE Proceedings from XIII Weurman Flavour Research Symposium}

Edited by

VICENTE FERREIRA

Laboratorio de Análisis del Aroma y Enología

RICARDO LOPEZ

Facultad de Ciencias, Universidad de Zaragoza,

Zaragoza, Spain 
Academic Press is an imprint of Elsevier

525 B Street, Suite 1900, San Diego, CA 92101-4495, USA

32 Jamestown Road, London NW1 7BY, UK

225 Wyman Street, Waltham, MA 02451, USA

Copyright (C) 2014 Elsevier Inc. All rights reserved

No part of this publication may be reproduced, stored in a retrieval system, or transmitted in any form or by any means electronic, mechanical, photocopying, recording or otherwise without the prior written permission of the publisher.

Permissions may be sought directly from Elsevier's Science \& Technology Rights Department in Oxford, UK: phone (+44) (0) 1865 843830; fax (+44) (0) 1865 853333; email: permissions@elsevier.com. Alternatively, visit the Science and Technology Books website at www.elsevierdirect.com/rights for further information.

\section{Notice}

No responsibility is assumed by the publisher for any injury and/or damage to persons, or property as a matter of products liability, negligence or otherwise, or from any use or operation of any methods, products, instructions or ideas contained in the material herein. Because of rapid advances in the medical sciences, in particular, independent verification of diagnoses and drug dosages should be made.

\section{British Library Cataloguing-in-Publication Data}

A catalogue record for this book is available from the British Library

\section{Library of Congress Cataloging-in-Publication Data}

A catalog record for this book is available from the Library of Congress

ISBN: 978-0-12-398549-1

For information on all Academic Press publications visit our website at elsevierdirect.com

Typeset by MPS Limited, Chennai, India www.adi-mps.com

Printed and bound in the United States of America

$\begin{array}{lllllllllllllll}13 & 14 & 15 & 16 & 17 & 10 & 9 & 8 & 7 & 6 & 5 & 4 & 3 & 2 & 1\end{array}$

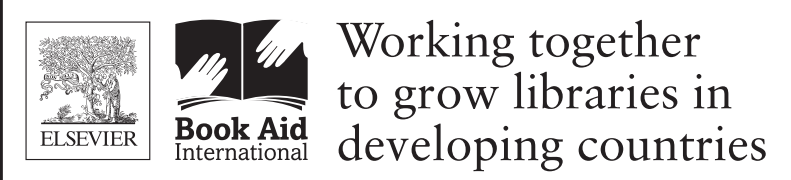

www.elsevier.com • www.bookaid.org 


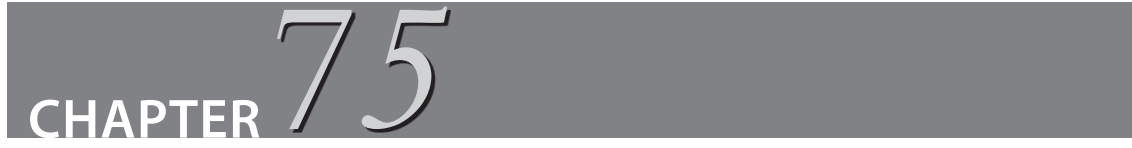

\section{Improvement of Partition Coefficients Determination of Aroma Compounds in Food Matrices by the Phase Ratio Variation Method}

\section{Anne Tromelin, Samuel Lubbers, Isabelle Andriot and Elisabeth Guichard}

Centre des Sciences du Goût et de l'Alimentation, UMR6265 CNRS, UMR1324 INRA, Université de Bourgogne, Agrosup Dijon, Dijon, France

\subsection{INTRODUCTION}

Before its perception, aroma compounds must move from the liquid phase towards the vapor phase, and aroma release from food matrices constitutes a determinant step for its perception. In previous works, we used the Quantitative Structure-Property Relationships (QSPR) approach to identify the nature of interactions involved between constituents of food matrix and aroma compounds [1]. In this way, a study of $\mathrm{K}=\mathrm{C}_{\mathrm{vap}} / \mathrm{C}_{\mathrm{liq}}$ at equilibrium is the usual method to account for the balance between liquid phase and vapor phase. Because QSPR methodology is based on statistical regression tools, a limitation of the QSPR approach is the size of the dataset. Indeed, good applicability conditions require a sufficiently large training set, constituted by at least 10 compounds belonging to the same chemical space [2]. However, partition coefficient determinations are based on headspace methods and are time-consuming because the quantification of aroma compounds in vapor phase by chromatographic experiment requires substance-response factor detector calibration.

The Phase Ratio Variation (PRV) method [3] allows one to overcome the calibration step. Ettre et al. [3,4] established the following Eq. 1, based on the influence of the volume of the sample on the concentration of volatiles in the headspace: 


$$
\frac{1}{A}=\frac{1}{f_{i} \times C_{\text {liq }}} \times K+\frac{1}{f_{i} \times C_{\text {liq }}} \times \beta
$$

where $\mathrm{A}$ is the chromatographic peak area at equilibrium, $\mathrm{f}_{\mathrm{i}}$ the proportional factor, $\mathrm{C}_{\mathrm{liq}}$ is the sample concentration, considered close to the initial concentration $\mathrm{C}_{\mathrm{o}}$ in the liquid phase, $\beta$ the ratio $\mathrm{V}_{\text {vapor }} / \mathrm{V}_{\text {liquid }}$ and $\mathrm{K}=[\text { volatile compound }]_{\text {liquid phase }} /[\text { volatile compound }]_{\text {vapor phase }}$ the partition coefficient between vapor phase and liquid phase. On the basis of the PRV equation, $\mathrm{K}$ is also equal to the ratio of slope and intercept of the linear regression $1 / \mathrm{A}$ vs. $\mathrm{b}$.

Nevertheless, there are some limitations to this method, particularly when compounds are strongly retained by food matrices [5], but also in case of very volatile molecules. However, as the PRV approach is a very valuable method for partition coefficients data acquisition, we have carefully examined its principle in order to improve the reliability of results.

\subsection{MATERIALS AND METHODS}

We consider that volumes remain constant: $V_{t}=V_{\text {liq }}+V_{\text {vap }}$, and $\mathrm{V}_{\text {liq(t0) }}=\mathrm{V}_{\text {liq(teq) }}$ (volume variation due to vaporization in vapor phase is negligible in comparison with $\mathrm{V}_{\text {liq }}$ ).

Our calculations are based on:

the law of conservation of mass $\left(n_{0}=n_{\text {vap }}+n_{\text {liq }}\right)$ which states that the mass of a closed system remains constant over time [6];

the partition coefficient value $\mathrm{K}=\mathrm{C}_{\text {vap }} / \mathrm{C}_{\text {liq }}$.

We have chosen two $\mathrm{K}$ values: $\mathrm{K}_{1}=10^{-3}$ and $\mathrm{K}_{2}=5.10^{-2}$ in the range of partition coefficient already known for aroma compounds [7,8], and performed the calculations for $12 \mathrm{~V}_{\text {liq }}$ values: $0.15 ; 0.2 ; 0.3 ; 0.4 ; 0.5 ; 0.75$; $1 ; 1.25 ; 1.5 ; 2 ; 3$; and $5 \mathrm{~mL}$. Initial liquid phase concentration was set to $\mathrm{C}_{0}=10^{-4} \mathrm{~mol} / \mathrm{L}$. Total volume was set to $21 \mathrm{~mL}$.

For each $\mathrm{V}_{\text {liq }}$, we calculated:

$$
\begin{aligned}
\mathrm{n}_{0}= & \mathrm{C}_{0} \times \mathrm{V}_{\text {liq }} \\
\mathrm{n}_{\text {vap }}= & \mathrm{C}_{\text {vap }} \times \mathrm{V}_{\text {vap }}=\mathrm{K} \times \mathrm{C}_{\text {liq }} \times \mathrm{V}_{\text {vap }}=\left(\mathrm{K} \times\left(\mathrm{V}_{\mathrm{t}}-\mathrm{V}_{\text {liq }}\right) \times \mathrm{n}_{0}\right) / \\
& \left(\mathrm{V}_{\text {liq }}+\mathrm{K} \times\left(\mathrm{V}_{t}-\mathrm{V}_{\text {liq }}\right)\right) \text { and } \mathrm{n}_{\text {liq }}=\mathrm{n}_{0}-\mathrm{n}_{\text {vap }} \\
\mathrm{C}_{\text {vap }}= & \mathrm{n}_{\text {vap }} / \mathrm{V}_{\text {vap }} \text { and } \mathrm{C}_{\text {liq }}=\mathrm{n}_{\text {liq }} / \mathrm{V}_{\text {liq }}
\end{aligned}
$$




\subsection{RESULTS}

According to Ettre et al. [3], the classical PRV equation writes:

$$
\begin{aligned}
& 1 / \mathrm{A}=\left(1 / \mathrm{f}_{\mathrm{i}} \mathrm{C}_{\mathrm{liq}}\right) \times \mathrm{C}_{\text {liq }} / \mathrm{C}_{\text {vap }}+\left(1 / \mathrm{f}_{\mathrm{i}} \mathrm{C}_{\mathrm{li}}\right) \times \beta \\
& \text { with } \beta=\mathrm{V}_{\text {vap }} / \mathrm{V}_{\text {liq }}
\end{aligned}
$$

PRV equation applicability is based on the assumption that the concentration of solute in liquid phase remains almost constant, thus close to the initial concentration $\mathrm{C}_{0}\left(\mathrm{C}_{\text {liq }} \approx \mathrm{C}_{0}\right)$. Indeed, considering a vapor phase sampling of $1 \mathrm{~mL}$ and expressing concentrations in $\mathrm{mmol} / \mathrm{mL}$ and volume in $\mathrm{mL}$, the PRV equation becomes:

$$
\begin{aligned}
& 1 / \mathrm{A}= 1 / \mathrm{f}_{\mathrm{i}} \mathrm{C}_{\text {vap }} \times 1=\left(1 / \mathrm{f}_{\mathrm{i}} \mathrm{C}_{\text {liq }}\right) \times \mathrm{C}_{\text {liq }} / \mathrm{C}_{\text {vap }}+\left(1 / \mathrm{f}_{\mathrm{i}} \mathrm{C}_{\mathrm{li}}\right) \times \mathrm{V}_{\text {vap }} / \mathrm{V}_{\text {liq }} \\
& 1 / \mathrm{C}_{\text {vap }}=\left(1 / \mathrm{C}_{\text {liq }}\right) \times \mathrm{C}_{\text {liq }} / \mathrm{C}_{\text {vap }}+\left(1 / \mathrm{C}_{\text {liq }}\right) \times \mathrm{V}_{\text {vap }} / \mathrm{V}_{\text {liq }}
\end{aligned}
$$

so that:

$$
1 / \mathrm{C}_{\mathrm{vap}}=1 / \mathrm{C}_{\mathrm{vap}}+\mathrm{V}_{\mathrm{vap}} /\left(\mathrm{C}_{\text {liq }} \mathrm{V}_{\text {liq }}\right)
$$

What is meant by the term $\mathrm{V}_{\mathrm{vap}} /\left(\mathrm{C}_{\text {liq }} \mathrm{V}_{\text {liq }}\right)$ ?

$$
1 / \mathrm{C}_{\text {vap }}+\mathrm{V}_{\text {vap }} /\left(\mathrm{C}_{\text {liq }} \mathrm{V}_{\text {liq }}\right)=\mathrm{V}_{\text {vap }} / \mathrm{n}_{\text {vap }}+\left(\mathrm{V}_{\text {liq }} / \mathrm{n}_{\text {liq }}\right) \times\left(\mathrm{V}_{\text {vap }} / \mathrm{V}_{\text {liq }}\right)
$$

and

$\mathrm{V}_{\text {vap }} / \mathrm{n}_{\text {vap }}+\left(\mathrm{V}_{\text {liq }} / \mathrm{n}_{\text {liq }}\right) \times\left(\mathrm{V}_{\text {vap }} / \mathrm{V}_{\text {liq }}\right)=\mathrm{V}_{\text {vap }} / \mathrm{n}_{\text {vap }}+\left(\mathrm{V}_{\text {liq }} \mathrm{V}_{\text {vap }}\right) /\left(\mathrm{n}_{\text {liq }} \cdot \mathrm{V}_{\text {liq }}\right)$

Hence

$$
1 / \mathrm{C}_{\text {vap }}+\mathrm{V}_{\text {vap }} /\left(\mathrm{C}_{\text {liq }} \mathrm{V}_{\text {liq }}\right)=\mathrm{V}_{\text {vap }} / \mathrm{n}_{\text {vap }} \times\left(\left(\mathrm{n}_{\text {liq }}+\mathrm{n}_{\text {vap }}\right) / \mathrm{n}_{\text {liq }}\right)
$$

so leads to $1 / \mathrm{C}_{\text {vap }}+\mathrm{V}_{\text {vap }} /\left(\mathrm{C}_{\text {liq }} \mathrm{V}_{\text {liq }}\right)=1 / \mathrm{C}_{\text {vap }} \times\left(\mathrm{n}_{0} / \mathrm{n}_{\text {liq }}\right)$ and if $\mathrm{n}_{\text {liq }} \approx \mathrm{n}_{0}, \mathrm{n}_{0} / \mathrm{n}_{\text {liq }} \approx 1$.

In this way, the term $\mathrm{V}_{\text {vap }} / \mathrm{C}_{\text {liq }} \mathrm{V}_{\text {liq }}$ appears as an "excess" term which becomes negligible if $n_{\text {liq }} \approx n_{0}$ and calculated $C_{\text {vap }}$ from $K$ and $n_{0}$ values appears as an ideal value, whereas the "real" $\mathrm{C}_{\text {vap }}$ value is equal to 
$\mathrm{C}_{\mathrm{vap}} \times\left(\mathrm{n}_{\text {liq }} / \mathrm{n}_{0}\right)$. "Ideal" and "real" $\mathrm{C}_{\mathrm{vap}}$ values are respectively called $\mathrm{C}_{\mathrm{vap}-}$ ideal and $\mathrm{C}_{\text {vap-real }}$ in the following text, and we can write:

$$
1 / \mathrm{C}_{\text {vap-real }}=\left(\mathrm{n}_{0} / \mathrm{n}_{\text {liq }}\right) \times 1 / \mathrm{C}_{\text {vap-ideal }}=\left(\mathrm{n}_{0} / \mathrm{n}_{\text {liq }}\right) \times\left(1 / \mathrm{KC}_{0}+\left(1 / \mathrm{C}_{\mathrm{o}}\right) \beta\right)
$$

Graphs of $1 / \mathrm{C}_{\text {vap }}$ vs. $\beta$ are reported in Figures 75.1 (a) and (b), respectively.

For both $\mathrm{K}_{1}$ and $\mathrm{K}_{2}$, linear regression calculation $1 / \mathrm{C}_{\text {vap-ideal }}$ vs. $\beta$ leads to obtain an ideal regression line, which slope and intercept are equal respectively to $1 / \mathrm{C}_{0}$ and $1 / \mathrm{C}_{0} \times \mathrm{C}_{\text {liq }} / \mathrm{C}_{\text {vap }}$. Conversely, $\mathrm{C}_{\text {vap-real }}$ seems to be a regression line for the less volatile compound $\left(K_{1}=0.001\right)$, but there is no rigorous linear correlation between $1 / \mathrm{C}_{\text {vap-real }}$ and $\beta$ as appears in Figure $75.1 \mathrm{~b}$ for the most volatile compound $\left(\mathrm{K}_{2}=0.05\right)$.

The inserts displayed in Figure 75.1(a) and (b) show the variation of concentration in vapor phase according to the $\mathrm{V}_{\text {liq }}$ values. For the most volatile compound the values increase for the whole range of $\mathrm{V}_{\text {liq }}$ values, but for the less volatile compound, these values stagnate for $\mathrm{V}_{\text {liq }}>0.75 \mathrm{~mL}$.

\subsection{DISCUSSION AND CONCLUSION}

The results summarized in Figure 75.1 highlight a deviation between the ideal PRV calculation, obtained using $\mathrm{C}_{\text {vap-ideal }}$ values, and a more realistic result obtained using $\mathrm{C}_{\text {vap-real }}$ that should reflect experimental conditions. This deviation remains low for the less volatile compound but significantly increases when volatility increases: the higher the volatility, the greater the deviation. Examination of the slope and intercept values obtained for $\mathrm{K}_{2}=0.05$ reveals a dramatic risk in providing erroneous $\mathrm{K}$ values.

In this way, the more reliable points are obtained for low $\beta$ values, so that large liquid volume and a good alternative would be to choose $\beta$ range corresponding to larger liquid volume $\left(\beta \leq 20\right.$ so that $\left.V_{\text {liq }} \geq 1 \mathrm{~mL}\right)$. It is already the best choice for the volatile compounds, but there is a technical limitation for the less volatile compounds. Indeed, because of the stagnation of concentrations in the vapor phase for volumes of liquid phase higher than $2 \mathrm{~mL}$ (inserts in Figure 75.1(a)), the weak experimental increase of chromatographic area values may be masked by background noise.

The study of the two examples given shows the crucial importance of an adequate choice of liquid volumes and $\beta$ range for an optimal use of PRV method and reliable determination of liquid-vapor partition coefficient values. 

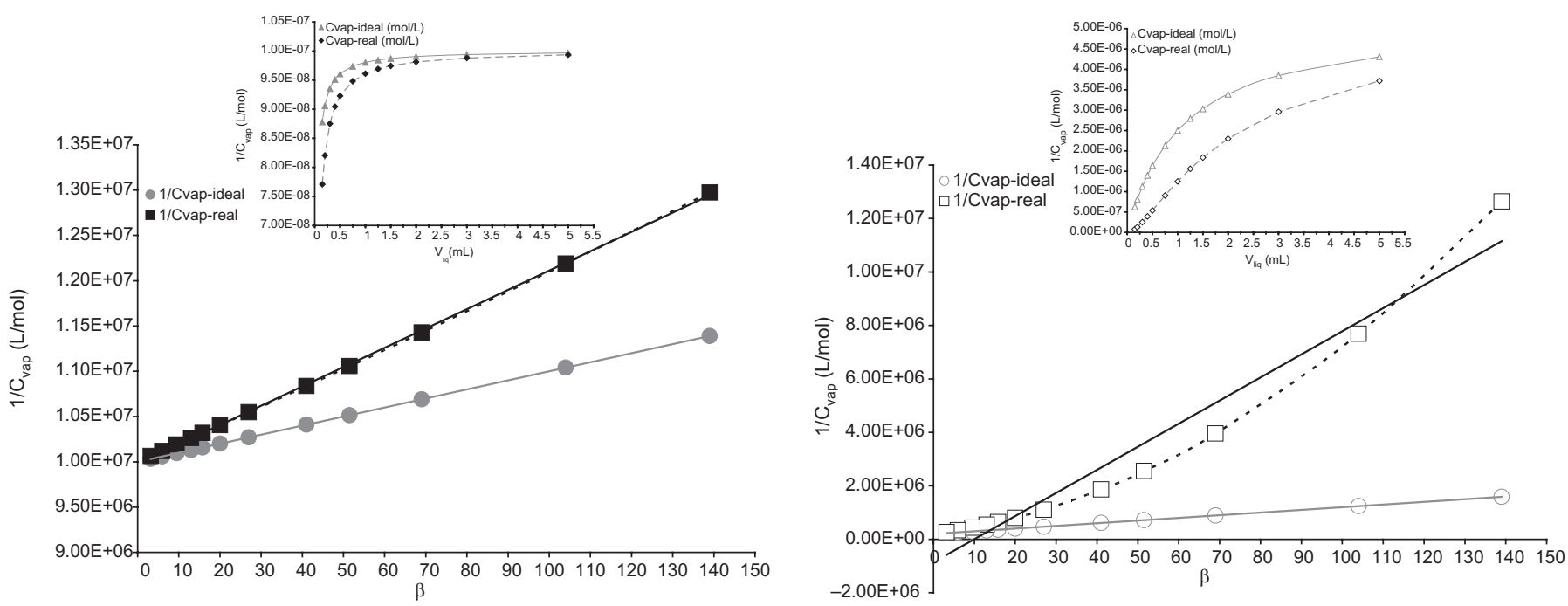

Figure 75.1 Graphical representation of regression plots $1 / C_{\text {vap }}$ vs. $\beta$ (left (a) $K_{1}=0.001$; right (b) $K_{2}=0.05$ ). Variations of $C_{\text {vap }}$ vs. volume of liquid phase are displayed in the inserts. 


\section{REFERENCES}

[1] A. Tromelin, E. Guichard, Interaction between flavour compounds and $\beta$-lactoglobulin: Approach by NMR and 2D/3D-QSAR studies of ligands, Flavour. Fragr. J. 21 (2006) $13-24$.

[2] P.P. Roy, J.T. Leonard, K. Roy, Exploring the impact of the size of training sets for the development of predictive QSAR models, Chemometrics Intell Lab Syst. 90 (2008) $31-42$.

[3] L.S. Ettre, C. Welter, B. Kolb, Determination of gas-liquid partition coefficients by automatic equalibrium headspace-gas, chromatography: utilizing the phase ratio variation method, Chromatographia 35 (1993) 73-84.

[4] L.S. Ettre, B. Kolb, Headspace-gas chromatography: the influence of sample volume on analytical results, Chromatographia 32 (1991) 5-12.

[5] C. Jouquand, V. Ducruet, P. Giampaoli, Partition coefficients of aroma compounds in polysaccharide solutions by the phase ratio variation method, Food Chem. 85 (2004) 467-474.

[6] X.S. Chai, J.Y. Zhu, Simultaneous measurements of solute content and Henry's constant by multiple extraction headspace gas chromatography, Anal. Chem. 70 (1998) 3481-3487.

[7] M. Kopjar, I. Andriot, A. Saint-Eve, I. Souchon, E. Guichard, Retention of aroma compounds: An interlaboratory study on the effect of the composition of food matrices on thermodynamic parameters in comparison with water, J. Sci. Food Agric. 90 (2010) 1285-1292.

[8] A. Tromelin, I. Andriot, M. Kopjar, E. Guichard, Thermodynamic and structure-property study of liquid-vapor equilibrium for aroma compounds, J. Agric. Food Chem. 58 (2010) 4372-4387. 